COSTING:Journal of Economic, Business and Accounting

Volume 4 Nomor 2, Juni 2021

e-ISSN : 2597-5234

\title{
PENGARUH STRUKTUR KEPEMILIKAN INSTITUSIONAL DAN FINANCIAL LEVERAGE TERHADAP MANAJEMEN LABA
}

\author{
EFFECTS OF INSTITUTIONAL OWNERSHIP STRUCTURE, \\ AND FINANCIAL LEVERAGE ON EARNINGS MANAGEMENT
}

\author{
Titania Ayudia $^{1}$, Nesti Hapsari ${ }^{2}$ \\ Universitas Singaperbangsa Karawang ${ }^{1.2}$ \\ titaniaayudiaed16@yahoo.com $^{1}$
}

\begin{abstract}
This study aims to determine whether there is an influence of Institutional Ownership Structure, Debt to Equity Ratio, and Debt to Asset Ratio to the Earnings Management partially or jointly. The method used in this research is descriptive method verification with a quantitative approach sourced from the annual financial statements on manufacturing companies sub sector of food and beverage, and literature studies. The sampling technique uses non probability sampling with purposive sampling technique. The data obtained were analyzed by testing the classic assumption, multiple linear regression analysis and hypothesis testing using $t$ test and $f$ test. This study uses the SPSS version 26 program to process data. The results of this study indicate that, Institutional Ownership Structure does not affect the Earnings Management, Debt to Equity Ratio (DER) have a negative and significant effect the Earnings Management, Debt to Asset Ratio (DAR) have a positive and significant effect the Earnings Management. And simultaneously Institutional Ownership Structure, Debt to Equity Ratio, and Debt to Asset Ratio have a affect the Earnings Management.
\end{abstract}

Keyword : Institutional Ownership Structure, Earnings Management.

\begin{abstract}
ABSTRAK
Penelitian ini bertujuan untuk mengetahui apakah terdapat pengaruh Struktur Kepemilikan Institusional, Debt to Equity Ratio, dan Debt to Asset Ratio terhadap Manajemen Laba secara parsial maupun bersama-sama. Metode yang digunakan dalam penelitian ini adalah metode deskriptif verifikatif dengan pendekatan kuantitatif yang bersumber dari laporan keuangan tahunan Perusahaan Sub Sektor Makanan dan Minuman, dan studi pustaka. Teknik pengambilan sampel mengunakan non probability sampling dengan teknik sampling purposive. Data yang diperoleh dianalisis dengan uji asumsi klasik, analisis regresi linier berganda dan uji hipotesis menggunakan uji t dan uji f. Penelitian ini menggunakan program SPSS versi 26 untuk mengolah data. Hasil penelitian ini menunjukan bahwa, Struktur Kepemilikan Institusional tidak berpengaruh terhadap Manajemen Laba, Debt to Equity Ratio berpengaruh negatif dan signifikan terhadap Manajemen Laba, Debt to Asset Ratio berpengaruh positif dan signifikan terhadap Manajemen Laba. Dan secara simultan Struktur Kepemilikan Institusional, Debt to Equity Ratio dan Debt to Asset Ratio berpengaruh terhadap Manajemen Laba.
\end{abstract}

Kata Kunci : Struktur Kepemilikan Institusional, Manajemen Laba. 


\section{PENDAHULUAN}

Pasar bebas menjadi peluang dan tantangan bagi produsen makanan dan minuman. Situasi bisnis ini, berhasil menciptakan persaingan pasar yang semakin ketat (Handoko, 2015). Suatu perusahaan dapat berkembang dan bertahan atau tidak dalam persaingan bisnis dapat diketahui melalui laporan keuangan perusahaan. Pada laporan keuangan yang disajikan oleh manajemen perusahaan memuat informasi laba (Dimarcia \& Krisnadewi, 2016).

Tujuan para stakeholder berinvestasi tidak lain untuk memperoleh keuntungan, maka dari itu sorotan utama stakeholder berinvestasi dalam pelaporan keuangan ialah informasi yang berkaitan dengan laba (Arthawan \& Wirasedana, 2018). Namun, para stakeholder tidak dapat secara bebas memperoleh informasi keuangan perusahaan yang sesungguhnya. Hal ini dikarenakan bahwa Informasi yang mereka peroleh terbatas pada laporan yang disediakan manajemen perusahaan (Soemarso, 2010).

Hal inilah satu dari berbagai alasan mengapa manajemen perusahaan memanfaatkan kebebasan (fleksibilitas) dalam memilih metode akuntansi selama masih dalam batasan ruang lingkup prinsip akuntansi berterima umum (Generally Accepted Accounting Principles) untuk memodifikasi laporan keuangan tersebut agar menghasilkan jumlah laba (earnings) yang diharapkan (Sadjiarto, 2019). Modifikasi terhadap penyajian laba yang dilakukan oleh manajemen perusahaan disebut manajemen laba.

Manajemen laba (Earnings management) merupakan aktivitas manajerial untuk mempengaruhi dan mengintervensi laporan keuangan (Sulistyanto, 2018). Struktur kepemilikan institusional, Debt to Equity Ratio dan Debt to Asset Ratio banyak digunakan dalam penelitian sebagai 3 (tiga) dari berbagai faktor yang memengaruhi manajemen laba. Beberapa penelitian terdahulu terkait dengan manajemen laba, struktur kepemilikan institusional, Debt to Equity Ratio dan Debt to Asset Ratio telah banyak dilakukan oleh Kodriyah (2015), Handoko (2015), Dimarcia \& Krisnadewi (2016), Arifin \& Destriana (2016), Kusumaningtyas \& Farida (2016), Faranita \& Darsono (2017), Aryanti et al (2017), Sari (2017), Susanto \& Majid (2017), Arthawan \& Wirasedana (2018), Prasojo \& Fatayati (2018), Sadjiarto et al (2019).

Menurut Arifin \& Destriana (2016) yang mengungkapkan bahwa parameter kepemilikan institusional melalui persentase kepemilikan jumlah saham yang dimiliki pihak institusi terhadap seluruh modal saham perusahaan yang beredar. Dan presentase Debt to Equity Ratio diukur dengan utang yang dibandingkan dengan ekuitas, sedangkan Debt to Asset Ratio diukur dengan utang yang dibandingkan dengan Asset (Samryn, 2015).

\section{METODE PENELITIAN}

Penelitian ini menggunakan metode penelitian deskriptif verifikatif dengan pendekatan kuantitatif. Adapun variabel yang digunakan terdiri dari 3 (tiga) Variabel bebas yaitu Struktur Kepemilikan Institusional (X1), Debt to Equity Ratio (X2), Debt to Asset Ratio (X3), dan Variabel terikat yaitu Manajemen Laba (Y). Populasi dalam penelitian ini yaitu perusahaan manufaktur sub sektor makanan dan minuman yang terdaftar di Bursa Efek Indonesia (BEI) periode 2014-2019. Teknik pengambilan sampel yang digunakan berupa nonprobability 
sampling dengan teknik sampling purposive.Terdapat 11 (sebelas) perusahaan makanan dan minuman yang memenuhi kriteria berikut ini :

1. Perusahaan makanan dan minuman yang terdaftar di BEI tahun 20142019.

2. Perusahaan makanan dan minuman yang mempublikasikan laporan keuangan tahunan teraudit berturutturut tahun 2014-2019.

3. Perusahaaan makanan dan minuman yang tidak mengalami kerugian tahun 2014-2019 secara berturutturut.

4. Perusahaan makanan dan minuman yang menggunakan mata uang rupiah untuk pelaporan laporan keuangan tahun 2014-2019.

5. Perusahaan makanan dan minuman yang memiliki data struktur kepemilikan institusional, Debt to Equity Ratio, Debt to Asset Ratio, dan Manajemen Laba.

Alat analisis data yang digunakan berupa SPSS versi 26 yang meliputi uji statistik deskriptif, uji asumsi klasik, uji regresi linear berganda, uji hipotesis $t$ dan $\mathrm{f}$, serta uji koefisien determinasi.

\section{HASIL DAN PEMBAHASAN Uji Statistik Deskriptif}

Tujuan dari analisis ini adalah untuk menggambarkan suatu data secara statistik. Hasil uji statistik deskriptif menunjukkan bahwa :

1. Selama periode pengamatan 20142019, variabel Struktur Kepemilikan Institusional (SKI) memiliki nilai keseluruhan sebesar $4598,00 \%$, nilai minimum sebesar $33,00 \%$ dan nilai maksimum sebesar $96,00 \%$ dengan nilai rata-rata sebesar $69,6667 \%$ dan standar deviasi sebesar 17,64290\%.

2. Variabel Debt to Equity Ratio (DER) selama periode pengamatan 20142019 memiliki nilai keseluruhan sebesar $5644,00 \%$, nilai minimum sebesar $9,00 \%$ dan nilai maksimum sebesar $303,00 \%$ dengan nilai ratarata sebesar $85,5152 \%$ dan standar deviasi sebesar 54,92743\%.

3. Variabel Debt to Asset Ratio (DAR) memiliki suatu kesamaan dengan variabel Debt to Equity Ratio (DER), dimana selama periode pengamatan 2014-2019, variabel Debt to Asset Ratio (DAR) memiliki nilai keseluruhan sebesar $2770,00 \%$, nilai minimum sebesar $7,00 \%$ dan nilai maksimum sebesar $75,00 \%$ dengan nilai rata-rata sebesar $41,9697 \%$ dan standar deviasi sebesar 16,07192\%.

4. Variabel Manajemen Laba (ML) selama periode pengamatan 20142019 memiliki nilai keseluruhan sebesar $0,91 \%$, nilai minimum sebesar $-0,24 \%$ dan nilai maksimum sebesar $0,26 \%$ dengan nilai rata-rata sebesar $0,0138 \%$ dan standar deviasi sebesar $0,07926 \%$.

\section{Uji Asumsi Klasik}

Uji asumsi klasik ini meliputi uji normalitas, uji multikolinearitas, uji autokorelasi, dan uji heterokedastisitas.

1. Hasil uji normalitas menunjukkan bahwa nilai signifikansi pada Asymp. Sig. (2-tailed) sebesar 0,097, yang berarti bahwa data tersebut memiliki nilai Asymp. Sig $>$ dari 0,05 sehingga dapat disimpulkan bahwa data yang digunakan dalam penelitian ini dapat dinyatakan berdistribusi normal

2. Hasil uji multikolinearitas menunjukkan bahwa nilai VIF untuk variabel $\mathrm{X} 1, \mathrm{X} 2, \mathrm{X} 3$ memiliki besaran nilai dibawah 10 , yakni $\mathrm{X} 1$ sebesar 1,029, X2 sebesar 7,199, dan X3 sebesar 7,146. Serta, nilai Tolerance untuk variabel X1, X2, X3 memiliki besaran nilai diatas 0,1 , yakni X1 sebesar 0,972, X2 sebesar 0,139 , dan X3 sebesar 0,140 . 
Berdasarkan hal tersebut dapat disimpulkan bahwa tidak terjadi gejala multikolinieritas antar variabel independen dalam model regresi, karena tidak terjadi kolinearitas yang tinggi antara variabel independen dalam persamaan regresi yang diperoleh.

3. Hasil uji autokorelasi diperoleh nilai Durbin-Watson sebesar 1,956 sehingga nilai Durbin-Watson di antara -2 dan +2 , itu berarti menunjukkan bahwa tidak terjadi autokorelasi pada variabel dalam penelitian ini.
4. Hasil uji heterokedastisitas menunjukkan gambar titik-titik plot data menyebar diatas dan dibawah atau disekitaran 0, titik-titik plot tidak mengumpul hanya di atas dan dibawah saja, penyebaran titik-titik plot data tidak membentuk pola bergelombang melebar kemudian menyempit dan melebar kembali, dan penyebaran titik-titik tidak berpola. Oleh karena itu, dapat disimpulkan bahwa pada model regresi bebas dari masalah heteroskedastisita dalam artian tidak terjadi heteroskedastisitas dalam penelitian ini.

\section{Uji Regresi Linear Berganda}

Hasil uji regresi linear berganda ditunjukan pada tabel 1 di bawah ini:

Tabel 1 Hasil Uji Regresi Linear Berganda

\begin{tabular}{|c|c|c|c|c|c|c|}
\hline \multicolumn{7}{|c|}{ Coefficients $^{a}$} \\
\hline \multirow{2}{*}{\multicolumn{2}{|c|}{ Model }} & \multicolumn{2}{|c|}{ Unstandardized Coefficients } & $\begin{array}{l}\text { Standardized } \\
\text { Coefficients }\end{array}$ & \multirow[b]{2}{*}{$\mathrm{T}$} & \multirow[b]{2}{*}{ Siq. } \\
\hline & & B & Std. Error & Beta & & \\
\hline 1 & (Constant) &,- 037 & ,049 & &,- 748 &, 457 \\
\hline & SKI &,- 001 & ,001 &,- 145 & $-1,216$ & ,229 \\
\hline & DER &,- 001 & 000 &,- 772 & $-2,454$ & 017 \\
\hline & DAR &, 005 &, 002 &, 923 & 2,944 &, 005 \\
\hline
\end{tabular}

a. Dependent Variable: $\mathrm{ML}$

Sumber : Hasil Olahan SPSS 26, 2020.

Dari hasil persamaan analisis regresi linier berganda diatas, maka diinterprestasikan beberapa hal antara lain sebagai berikut :

1. Nilai konstanta $(\alpha)$ adalah sebesar 0,037 . Hal ini berarti jika tidak ada perubahan variabel independen yaitu Struktur Kepemilikan Institusional (X1), Debt to

2. Equity Ratio (DER) (X2), dan Debt to Asset Ratio (DAR) (X3) sebelumnya maka variabel dependen yaitu Manajemen Laba (Y) akan tetap bernilai sebesar -0,037.

3. Variabel Struktur Kepemilikan Institusional (X1) memiliki nilai koefisien regresi negatif, hal ini menunjukkan bahwa adanya hubungan tidak searah antara Struktur Kepemilikan Institusional (X1) dengan Manajemen Laba (DA) (Y). Koefisien regresi variabel X1 yaitu sebesar -0,001, yang berarti bahwa setiap pertambahan atau kenaikan tingkat Struktur Kepemilikan Institusional yang dapat mengakibatkan penurunan Manajemen Laba (DA) atau dengan kata lain kenaikan Struktur Kepemilikan Institusional sebesar satu satuan akan mengakibatkan menurunnya Manajemen Laba (DA) sebesar -0,001 satuan, dengan asumsi Manajemen Laba (DA) dalam keadaan konstan. 
4. Variabel Debt to Equity Ratio (DER) (X2) memiliki nilai koefisien regresi negatif, hal ini menunjukkan bahwa adanya hubungan tidak searah antara Debt to Equity Ratio (DER) (X2) dengan Manajemen Laba (DA) (Y). Koefisien regresi variabel $\mathrm{X} 2$ yaitu sebesar -0,001, yang berarti bahwa setiap pertambahan atau kenaikan tingkat Debt to Equity Ratio (DER) (X2) yang dapat mengakibatkan penurunan Manajemen Laba (DA) atau dengan kata lain kenaikan Debt to Equity Ratio (DER) (X2) sebesar satu satuan akan mengakibatkan menurunnya Manajemen Laba (DA) sebesar -0,001 satuan, dengan asumsi Manajemen Laba (DA) dalam keadaan konstan.

5. Variabel Debt to Asset Ratio (DAR) (X3) memiliki nilai koefisien regresi positif, hal ini menunjukkan bahwa adanya hubungan searah antara Debt to Asset Ratio (DAR) dengan Manajemen Laba (DA). Koefisien regresi variabel X3 yaitu sebesar 0,005 , yang berarti bahwa setiap pertambahan atau kenaikan tingkat Debt to Asset Ratio (DAR) yang dapat mengakibatkan peningkatan Manajemen Laba (DA) atau dengan kata lain kenaikan Debt to Asset Ratio (DAR) sebesar satu satuan akan mengakibatkan meningkatnya Manajemen Laba (DA) sebesar 0,005 satuan, dengan asumsi Manajemen Laba (DA) dalam keadaan konstan.

\section{Uji Hipotesis T}

Hasil uji t ditunjukan pada tabel 2 di bawah ini:

Tabel 2 Hasil Uji T (Parsial)

Coefficients $^{\mathrm{a}}$

\begin{tabular}{|c|c|c|c|c|c|c|c|c|}
\hline \multirow[b]{2}{*}{ Mode } & & \multicolumn{2}{|c|}{$\begin{array}{l}\text { Unstandardized } \\
\text { Coefficients }\end{array}$} & \multirow{2}{*}{$\begin{array}{c}\text { Standardized } \\
\text { Coefficients } \\
\text { Beta }\end{array}$} & \multirow[b]{2}{*}{ T } & \multirow[b]{2}{*}{ Sig. } & \multicolumn{2}{|c|}{ Collinearity Statistics } \\
\hline & & & $\begin{array}{l}\text { Sta. } \\
\text { Error }\end{array}$ & & & & Tolerance & VIF \\
\hline \multirow[t]{4}{*}{1} & (Constant) &,- 037 & ,049 & &,- 748 & ,457 & & \\
\hline & SKI &,- 001 & 001 &,- 145 & $-1,216$ & ,229 & ,972 & 1,029 \\
\hline & DER &,- 001 & ,000 &,- 772 & $-2,454$ & 017 & , 139 & 7,199 \\
\hline & DAR &, 005 &, 002 & ,923 & 2,944 & ,005 & 140 & 7,146 \\
\hline
\end{tabular}

a. Dependent Variable: ML

Sumber : Hasil Olahan SPSS 26, 2020.

Berdasarkan hasil pengujian untuk variabel X1 Struktur Kepemilikan Institusional pada tabel diatas, diperoleh nilai thitung sebesar -1,216. Jika dibandingkan dengan nilai $\mathrm{t}_{\text {tabel }}$ yaitu sebesar 1,99714 sehingga nilai $t_{\text {hitung }}<$ $t_{\text {tabel. }}$ Sedangkan nilai signifikansinya yaitu sebesar 0,229 yaitu lebih besar dari 0,05 atau $0,229>0,05$. Oleh karena itu dapat disimpulkan $\mathrm{H}_{0}$ diterima dan $\mathrm{H}_{1}$ ditolak. Dengan secara parsial variabel Struktur Kepemilikan
Institusional tidak berpengaruh terhadap variabel Manajemen Laba.

Hasil pengujian untuk variabel X2 yaitu, Debt to Equity Ratio (DER) pada tabel diatas, diperoleh nilai thitung sebesar -2,454. Jika dibandingkan dengan nilai tabel yaitu sebesar 1,99714 sehingga nilai $t_{\text {hitung }}>t_{\text {tabel }}$. Sedangkan nilai signifikansinya yaitu sebesar 0,017 yaitu lebih kecil dari 0,05 atau 0,017< 0,05 . Oleh karena itu dapat disimpulkan $\mathrm{H}_{0}$ ditolak dan $\mathrm{H}_{2}$ diterima. Dengan secara parsial variabel Debt to Equity Ratio (DER) berpengaruh negatif dan 
signifikan terhadap variabel Manajemen Laba.

Hasil pengujian untuk variabel X3 yaitu, Debt to Asset Ratio (DAR) pada tabel diatas, diperoleh nilai thitung sebesar 2,944. Jika dibandingkan dengan nilai $t_{\text {tabel }}$ yaitu sebesar 1,99714 sehingga nilai $t_{\text {hitung }}>t_{\text {tabel. }}$. Sedangkan nilai signifikansinya yaitu sebesar sebesar 0,017 yaitu lebih kecil dari 0,05 atau $0,005<0,05$. Oleh karena itu dapat disimpulkan $\mathrm{H}_{0}$ ditolak dan $\mathrm{H}_{3}$ diterima. Dengan secara parsial variabel Debt to Asset Ratio (DAR) berpengaruh positif dan signifikan terhadap variabel Manajemen Laba.

\section{Uji Hipotesis F}

Hasil uji f dapat ditunjukan pada tabel 3 di bawah ini:

Tabel 3 Hasil Uji F (Simultan)

\begin{tabular}{lrrrrrr}
\multicolumn{7}{c}{ ANOVA $^{\mathbf{a}}$} \\
\hline Model & Sum of Squares & df & Mean Square & F & Sig. \\
\hline 1 & Regression &, 060 & 3 &, 020 & 3,550 &, $019^{\mathrm{b}}$ \\
& Residual &, 348 & 62 &, 006 & & \\
&, 408 & 65 & & & \\
\hline
\end{tabular}

a. Dependent Variable: ML

b. Predictors: (Constant), DAR, SKI, DER

Sumber: Hasil Olahan SPSS 26, 2020.

Hasil menunjukkan nilai 3,550 > 2,75 yaitu, nilai $f_{\text {hitung }}>f_{\text {tabel. }}$. Nilai signifikansi sebesar 0,019 lebih kecil dari 0,05. Sehingga $\mathrm{H}_{0}$ ditolak dan $\mathrm{H}_{4}$ diterima. Dengan demikian, dapat disimpulkan variabel Struktur Kepemilikan Institusional, Debt to
Equity Ratio (DER), dan Debt to Asset Ratio (DAR) berpengaruh positif dan signifikan terhadap Manajemen Laba secara bersama-sama.

\section{Uji Koefisien Determinasi $\left(\mathbf{R}^{\mathbf{2}}\right)$}

Hasil uji koefisien determinasi dapat ditunjukan pada tabel 4 di bawah in

Tabel 4 Hasil Uji R $^{2}$

Model Summary ${ }^{b}$

\begin{tabular}{|c|c|c|c|c|c|}
\hline $\begin{array}{l}\text { Mod } \\
\text { el }\end{array}$ & $\mathrm{R}$ & R Square & $\begin{array}{l}\text { Adjusted R } \\
\text { Square } \\
\end{array}$ & $\begin{array}{l}\text { Std. Error of the } \\
\text { Estimate }\end{array}$ & Durbin-Watson \\
\hline 1 &, $383^{a}$ & 147 & ,105 & ,07497 & 1,956 \\
\hline
\end{tabular}


Hasil uji pada tabel 4 menunjukkan bahwa nilai R Square atau nilai koefisien determinasi sebesar 0,147 atau $14,7 \%$. Hal ini menunjukkan bahwa variabel yang di teliti yaitu SKI, DER, dan DAR berpengaruh sebesar 14,7\%. terhadap Manajemen Laba (DA). Sedangkan sisanya yaitu sebesar $85,3 \%(100 \%-14,7 \%)$ dipengaruhi oleh variabel lain yang tidak diteliti dalam penelitian ini.

\section{Pengaruh Struktur Kepemilikan Institusional terhadap Manajemen Laba}

Berdasarkan uji hipotesis $t$ bahwa secara parsial variabel Struktur Kepemilikan Institusional tidak berpengaruh terhadap variabel Manajemen Laba. Maka dapat disimpulkan bahwa tidak terdapat pengaruh Struktur Kepemilikan Institusional terhadap Manajemen Laba. Investor institusi yang memiliki saham mayoritas pada perusahaan, pada umumnya mendelegasikan pengelolaan investasinya pada pihak yang profesional dalam bidang analis dan keuangan, sehingga investor institusi tidak dapat melakukan pengawasan secara langsung. Hal ini, tidak menutup kemungkinan pihak manajemen perusahaan untuk mempengaruhi analis tersebut untuk melaporkan hasil yang tidak sesuai kondisi sebenarnya.

Hasil penelitian ini sejalan dengan hasil penelitian Kodriyah (2015), Faranita \& Darsono (2017). Aryanti et al (2017), Handoko (2015) yang menyatakan bahwa Struktur Kepemilikan Institusional tidak berpengaruh terhadap Manajemen Laba

\section{Pengaruh Debt to Equity Ratio terhadap Manajemen Laba}

Berdasarkan uji hipotesis $\mathrm{t}$ bahwa dengan secara parsial variabel Debt to Equity Ratio (DER) berpengaruh negatif dan signifikan terhadap variabel Manajemen Laba.

Maka dapat disimpulkan bahwa terdapat pengaruh negatif dan signifikan Debt to Equity Ratio (DER) terhadap Manajemen Laba. Hasil penelitian ini menunjukkan bahwa semakin meningkatnya Debt to Equity Ratio (DER) maka perusahaan tersebut berarti memiliki kewajiban kepada pihak ketiga yang meningkat. Hal ini disebabkan karena modal yang dimiliki perusahaan tidak melebihi Utang perusahaan. Kondisi bertambahnya pinjaman perusahaan tersebut akan membuat laporan keuangan kurang baik dimata investor. Sehingga dapat mempengaruhi tindakan Manajemen laba (DA), hal ini dikarenakan resiko akan gagal bayar yang meningkat.

Hasil penelitian ini sejalan dengan hasil penelitian Arthawan \& Wirasedana (2018) yang menyatakan bahwa Debt to Equity Ratio (DER) secara parsial berpengaruh negatif dan signifikan terhadap Manajemen Laba.

\section{Pengaruh Debt to Asset Ratio terhadap Manajemen Laba}

Berdasarkan uji hipotesis $\mathrm{t}$ bahwa secara parsial variabel Debt to Asset Ratio (DAR) berpengaruh positif dan signifikan terhadap variabel Manajemen Laba. Maka dapat disimpulkan bahwa terdapat pengaruh positif dan signifikan Debt to Asset Ratio (DAR) terhadap Manajemen Laba. Hasil penelitian ini menunjukkan bahwa semakin meningkatnya Debt to Asset Ratio (DAR) maka perusahaan tersebut berarti memiliki kewajiban kepada pihak ketiga yang meningkat. Hal ini disebabkan karena Asset yang dimiliki perusahaan tidak melebihi Utang perusahaan.

Kondisi bertambahnya pinjaman perusahaan tersebut akan membuat laporan keuangan kurang baik dimata 
investor. Sehingga dapat mempengaruhi peningkatan tindakan Manajemen laba (DA), hal ini dikarenakan resiko akan gagal bayar yang meningkat.

Hasil penelitian ini sejalan dengan hasil penelitian Faranita \& Darsono (2017), Prasojo \& Fatayati (2018) yang menyatakan bahwa Debt to Asset Ratio (DAR) secara parsial berpengaruh positif dan signifikan terhadap Manajemen Laba.

\section{Pengaruh Struktur Kepemilikan Institusional, Debt to Equity Ratio, Debt to Asset Ratio terhadap Manajemen Laba}

Berdasarkan uji hipotesis $\mathrm{f}$ dapat disimpulkan terdapat pengaruh Struktur Kepemilikan Institusional, Debt to Equity Ratio (DER), dan Debt to Asset Ratio (DAR) berpengaruh positif dan signifikan terhadap Manajemen Laba secara bersama-sama.

Hasil penelitian ini sejalan dengan hasil penelitian Kodriyah (2015), Kusumaningtyas \& Farida (2016), Susanto \& Jamaluddin (2017), Sadjiarto (2019) yang menyatakan bahwa Struktur Kepemilikan Institusional, Debt to Equity Ratio (DER), dan Debt to Asset Ratio (DAR) berpengaruh positif dan signifikan terhadap Manajemen Laba.

\section{PENUTUP}

\section{Kesimpulan}

Berdasarkan hasil analisis data dan pembahasan mengenai pengaruh struktur kepemilikan institusional, debt to equity ratio, dan debt to asset ratio terhadap manajemen laba pada perusahaan manufaktur sub sektor makanan dan minuman periode 20142019, maka dapat ditarik kesimpulan sebagai berikut :

1. Struktur kepemilikan institusional tidak berpengaruh terhadap manajemen laba.
2. Debt to equity ratio berpengaruh negatif dan signifikan terhadap manajemen laba.

3. Debt to asset ratio berpengaruh positif dan signifikan terhadap manajemen laba.

4. Struktur kepemilikan institusional, debt to equity ratio, dan debt to asset ratio berpengaruh secara simultan terhadap manajemen laba.

\section{Saran}

Berdasarkan hasil analisis data, pembahasan, dan kesimpulan maka penulis memberikan saran yaitu:

1. Saran Bagi Perusahaan, meskipun investor institusi yang memiliki kepemilikan yang besar tidak bertindak sebagai investor yang cermat dalam mengawasi kinerja manajemen perusahaan, manajemen perusahaan hendaknya bertindak mengutamakan kepentingan perusahaan dibandingkan dengan kepentingan manajemen. Terlebih apabila manajemen perusahaan memiliki kepemilikan pula didalam perusahaan. Perusahaan hendaknya harus lebih bijak dalam mengambil keputusan dalam memilih sumber pendanaan yang sesuai dengan kemampuan perusahaan. Dan, perusahaan sebaiknya lebih selektif dalam mengalokasikan pendanaan yang tepat.

2. Saran Bagi Peneliti Selanjutnya, Diharapkan untuk peneliti selanjutnya agar bisa meneliti faktor lain yang dapat mempergaruhi struktur kepemilikan institusional, debt to equity ratio, dan debt to asset ratio terhadap manajemen laba. Sehingga hasil penelitian selanjutnya tersebut dapat dibandingkan dengan hasil penelitian penulis. Disarankan juga untuk menambahkan variabel independen lainnya dan juga 
penelitian ini bisa dilakukan dengan menambahkan periode penelitian sehingga jumlah sampel yang digunakan pada penelitian selanjutnya akan bertambah, guna memperoleh hasil penelitian yang lebih signifikan serta menggunakan metode dan alat uji yang lebih lengkap dan akurat sehingga diperoleh kesimpulan yang lebih valid.

\section{DAFTAR PUSTAKA}

Arifin, L., \& Destriana, N. (2016). Pengaruh Firm Size, Corporate Governance, dan Karakteristik Perusahaan terhadap Manajemen Laba. Jurnal Bisnis dan Akuntansi, 18(1):1410-9875.

Arthawan, P. T., \& Pradnyantha, I. W. (2018). Pengaruh Kepemilikan Manajerial, Kebijakan Utang dan Ukuran Perusahaan Terhadap Manajemen Laba, 22(1).

Aryanti, I., Kristanti, F. T., \& Hendratno, H. (2017). Kepemilikan Institusional, Kepemilikan Manajerial, dan Kualitas Audit terhadap Manajemen Laba. Jurnal Riset Akuntansi Kontemporer, 9(2):66-70.

Astari, N. K. R., \& Suputra, I. D. G. D. (2019). Pengaruh Ukuran Perusahaan, Kepemilikan Manajerial, dan Kinerja Keuangan Pada Manajemen Laba, 26(3).

Dimarcia, N. L. F. R., \& Krisnadewi, K. A. (2016). Pengaruh Diversifikasi Operasi, Leverage, dan Kepemilikan Manajerial pada Manajemen Laba, 15(3).

Faranita, W. A., \& Darsono. (2017). Pengaruh Leverage, Struktur Kepemilikan, dan Kualitas Audit terhadap Manajemen Laba, 6(3).
Handoko, B. L. (2015). The Effect of Institutional Ownership and Leverage Towards Profit Management in Consumer Goods Industry Listed in BEI, 6(3):414-423.

Kodriyah. (2015). Good Corporate Governance terhadap Manajemen Laba (Studi Empiris Pada Perusahaan Manufaktur yang Terdaftar di BEI 20092012). Jurnal Akuntansi, 2(1).

Kusumaningtyas, M., \& Farida, D. N. (2016). The Influence of Audit Committee and Ownership Structure on Earnings Management. Jurnal Dinamika Akuntansi, 8(1), 1-13.

Prasojo., \& Fatayati, I. R. (2018). Pengaruh Kinerja Perusahaan Terhadap Praktik Manajemen Laba Pada Emiten Indeks Saham Syariah Indonesia, 11(1).

Sadjiarto, A., Monica, C. C., \& Budiarti, W. R. (2019). Ownership Structure and Earnings Management in Indonesian Listed Banks. Journal of Economics and Business, 2(2):261-272.

Samryn, L. M. (2015). Pengantar Akuntansi : Buku 1 Siklus Akuntansi untuk Usaha Jasa, Perdagangan dan Industri Manufaktur Usaha Perorangan dan Perseroan Terbatas. Jakarta: Raja Grafindo Persada

Sari, A. L. (2017). Karakteristik Perusahaan, Tata Kelola Perusahaan dan Manajemen Laba. Vol Jurnal Akuntansi Bisnis, 15(2). 
Sari, N. H., \& Ahmar, N. (2014).

Revenue Discretionary Model

Pengukuran Manajemen Laba:

Berdasarkan Sektor Industri

Manufaktur di Bursa Efek

Indonesia. Jurnal Akuntansi dan Keuangan, 16(1): 43-51.

Soemarso. (2010). Akuntansi Suatu Pengantar Revisi Buku 2 Edisi 5. Jakarta: Salemba Empat.

Sulistyanto, H. S. (2018). Manajemen Laba: Teori dan Model Empiris. Jakarta: PT Gramedia Widiasarana Indonesia.

Susanto, I. R., \& Majid, J. (2017). Faktor-faktor yang Mempengaruhi Manajemen Laba pada Perusahaan Manufaktur di Bursa Efek Indonesia. Jurnal Ilmiah Akuntansi Peradaban. 3(2). 